Theories \& Applications, the International Edition

Printed Version : (ISSN 2090-5262)

Online Version : (ISSN 2090-5270)

November 2014, Volume 4, No. 3 Pages (122 - 126)

\title{
The Effect of the Educational Program of Basketball on the Skills Variables and Reducing Behavioral Deviations of Orphans Children.
}

\section{Dr. Adel Ramadan Bekhit}

Assistant professor, Department of origins physical education and recreation, college of physical Education, Sadat University, Egypt.

\begin{abstract}
The research aims to identify the impact of the educational program for technical learning of offensive skills of basketball and improving the physical and cognitive abilities of orphan children as well as reducing the deviations in behavior, The researcher used the experimental method, The research sample include 15 illegitimate orphaned girls from Ibnati Association in 6th October City. Average age: $14.8 \pm 0.45$, average height: $159.8 \pm 2.88$ and average weight: $53.3 \pm 3.79$, Results; statistically significant differences between the pre and post measurements in some physical and technical variables as well as the cognitive tests and behavioral deviations measurements in favor of post measurements.
\end{abstract}

Key Word : basketball, skills, reducing behavioral, orphans, children.

\section{Introduction}

$\mathrm{E}$ ducational and social science focus on orphans children as a special social groupbecause they need educational, psychological, and social attention which help them to integrate into society, and overcome their conditions of losing their families which leads to lack of social activities.The loss of a father, mother, or both of them lead to strong psychological pressure on the individual which may prevent him from leading a normal balanced life because the child did not find the support which help him to overcome this ordeal and guide him to the proper behavior and productive work. [6]

Naglaa Abbas indicates that a child who growup away from his family usually have a delayin his physical, mental and emotional development beside he generatea sense of inferiority which may lead to self-rejection and rejection of others. [21] On the other hand, the loss of family care negatively affects some social and psychological aspectsof the orphans such as lack of self-confidence and social growth as well as lack of physical motor skills. [20]

A behavioral deviation is one of the problems that adversely affects the child's behavior and impede his social or psychological efficiency in the society [8].

Behavioral deviation means all bad or obnoxious behavior of the child which harms him and others. [1]

Mahmoud Al Sayed (2010) refers in his study that behavioral deviation appears in the image of some symptoms, such as lying, aggression and disobedience as well as other rejected social behaviors.[16]

Somen 1984 also indicates that the most important problem in Orphanages is the lack of sports programs. [21]There are no various kinds of tracks inOrphanages, which makes it difficult to those children to achieve the physical education goals [2]
There are various methods which may have educational effects on these youngsters, but the most successful method is the one lead by individual's desire and self-motivated. Sport activities represent one of the best methods that can be invested in this area. [14]From this perspective, the importance of physical education and sport in general is demonstrated in orphanages through the practice of sports activities that can invest different sports situations indeveloping cooperation qualities and team spirit as well asreducing the feeling of inferiority, in addition it helps in the formation of Integrated personality of orphan children. [2]

Sportdevelops the personality of youngsters up to puberty as well as social awareness, beside, itcontributes to the elimination of aggressive behaviors and allow youngsters to achieve self-realizationand develop physical and motor abilities, which in turn helpin developing selfconfidence.[5]On the other hand, the great effort made when performing different sport exercises makes sports activities a preventive and therapeutic mean against various behavior deviations. [13]

Basketball has great prestige among other sports in terms of its popularity because the nature of basketball makes people of various categories busy watching and practicing it. Basketball is one of the most valuable sports activities for young people of both sexes. [27]For those youngsters, basketball is an excellent educational opportunity in addition; it contributes to enhance the physical abilities. Reza Baledi2011 has pointed to the positive changes on the social development and physical abilities and skillsof a group of youngsters after undergoing skillful basketball program.[31]

The researchers have used the following references to configure the content of the training program for offensive skills in basketball [10][11][17][25][28][29] 


\section{The Objective:}

The research identify the impact of the educational program for technical learning of offensive skills of basketball and improving the physical and cognitive abilities of orphan children as well as reducing the deviations in behavior.

\section{The Hypothesis:}

1. There are statistically significant differences between the pre and post measurementsin the physical variables in favor of the post measurement.

2. There are statistically significant differences between the pre and post measurements in the in the offensive skills of basketball in favor of the post measurement.

3. There are statistically significant differences between the pre and post measurements in the cognitive achievement of basketball approach in favor of the post measurement.

4. There are statistically significant differences between the pre and post measurements in reducing the deviations in behavior in favor of the post measurement

\section{Research Procedures:}

\section{Methodology:}

The researcher used the experimental method due to its relevance to the nature of the research. He used the pre-post measurements for the physical variables and offensive skills of basketball for the research sample and the pre-post measurements in the cognitive achievement in basketball, as well as measuring the deviations in behavior of the research sample.

\section{Sample:}

The research sample include 15 illegitimate orphaned girls from Ibnati Association in 6th October City. Averageage: $14.8 \pm 0.45$, average height: $159.8 \pm 2.88$ and average weight: $53.3 \pm 3.79$.

The coefficient body torsion and physical variables between (0.11-0.83), in the skill variables and cognitive test between (0.11 - 0.90), the technique variables between $(0.12-0.43)$.

Table(1)

The Mean , meddle, Sd. And skwness in the physical and technique variables, cognitive tests and behavioral deviations. $\mathrm{N}=15$

\begin{tabular}{|c|c|c|c|c|}
\hline Variables & Mean & Meddle & \pm SD & Skwness \\
\hline Flexibility & 159.8 & 160.0 & 2.88 & 0.24 \\
\hline Aerobic Endurance & 53.3 & 53.0 & 3.79 & 0.12 \\
\hline Muscular capacity & 14.8 & 15.0 & 0.45 & 0.83 \\
\hline Speed & 1.13 & 2.00 & 2.85 & 0.86 \\
\hline Strength endurance & 59.33 & 62.0 & 11.61 & 0.64 \\
\hline Agility & 128.6 & 120.0 & 2.23 & 0.84 \\
\hline Free-throw Shooting & 1.00 & 1.00 & 0.93 & 0.62 \\
\hline Passing & 10.00 & 10.00 & 0.85 & 0.82 \\
\hline Lay-up Shooting & 1.2 & 1.00 & 0.68 & 0.26 \\
\hline Dribbling & 11.43 & 12.00 & 2.24 & 0.90 \\
\hline Cognitive test & 3.8 & 4.00 & 0.56 & 0.11 \\
\hline Aggressive & 7.93 & 8.00 & 1.86 & 0.12 \\
\hline Relielition & 9.26 & 10.00 & 2.81 & 0.22 \\
\hline Lying & 8.73 & 9.00 & 1.62 & 0.43 \\
\hline Total & 25.92 & 26.00 & 4.38 & 0.42 \\
\hline
\end{tabular}


Show in table ( 1 ) The Mean, meddle, Sd. And skwness in the physical and technique variables, cognitive tests and behavioral deviations.

\section{Research Tests:}

\section{Physical tests:}

- $\quad$ Legs muscular ability: broad jump

- $\quad$ Transition speed : dynamic 30m sprint

- $\quad$ Agility : BarrowZig -zig- run

- Muscular endurance : sit-up

- Aerobic Endurance: running in place

- $\quad$ Flexibility: trunk forward bend while sitting

\section{Skill (technique) tests:}

- Lay-up shooting test

- Free-throw shot Test

- Dribble Zig - zig

- Passing speed test
These tests have been applied in many studies and references [9][15][24] where high sincerity coefficients have been proved which indicate the sincerity of their content.

\section{The cognitive test}

The cognitive test was designed to identify how much the research sample has acquired the basketball approach.The researcher has draft the questions of the test and put it in a form that includes ten vocabularies. Some phrases have been amended to get the final form of the test for application.

The researcher has used the following references in designing the cognitive test [4][12]

\section{The psychological test :}

The researcher has used behavioral deviations measurements of orphanage children .

\section{pre test}

The pre test at from $19-1-2013$ to $23-1-2013$.

\section{Main study :}

The main study at from $25-1-2013$ to $22-2-2013$.

post test

The post test at from $1-3-2013$ to $2-3-2013$.

Results

Table(2)

Significance differences between the pre and post measurements in the physical and technique variables, cognitive tests and behavioral deviations $\mathrm{N}=15$

\begin{tabular}{|c|c|c|c|c|c|c|}
\hline \multirow{2}{*}{ Variables } & \multicolumn{2}{|c|}{ Pre-measurement } & \multicolumn{2}{|c|}{ Post- measurement } & \multirow{2}{*}{$\begin{array}{c}\text { Ratio } \\
\text { ofimprovement }\end{array}$} & \multirow{2}{*}{ t. } \\
\hline & $\mathrm{m}$ & $\pm \mathrm{SD}$ & $\mathrm{m}$ & $\pm \mathrm{SD}$ & & \\
\hline Flexibility & 1.13 & 2.85 & 4.93 & 1.22 & $\% 77.07$ & 5.56 \\
\hline Aerobic Endurance & 59.33 & 11.61 & 70.2 & 11.44 & $\% 18.32$ & 3.52 \\
\hline Muscular capacity & 128.6 & 2.23 & 177.3 & 1.75 & $\% 37.87$ & 4.46 \\
\hline Speed & 7.77 & 1.24 & 4.96 & 0.52 & $\% 36.16$ & 9.19 \\
\hline Strength endurance & 23.8 & 7.37 & 35.33 & 10.58 & $\% 48.44$ & 1.77 \\
\hline Agility & 12.28 & 0.93 & 9.62 & 0.40 & $\% 21.66$ & 6.83 \\
\hline Free-throw Shooting & 1.00 & 0.93 & 3.73 & 2.12 & $\% 73.19$ & 8.84 \\
\hline Passing & 10.00 & 0.85 & 11.93 & 1.09 & $\% 19.3$ & 9.34 \\
\hline Lay-up Shooting & 1.2 & 0.68 & 2.46 & 0.83 & $\% 51.21$ & 8.98 \\
\hline Dribbling & 11.43 & 2.24 & 7.77 & 1.25 & $\% 32.02$ & 6.52 \\
\hline Cognitive test & 3.8 & 0.56 & 7.33 & 1.04 & $\% 100.00$ & 3.83 \\
\hline Aggressive & 7.93 & 1.86 & 12.66 & 1.76 & $\% 59.65$ & 4.51 \\
\hline Relielition & 9.26 & 2.81 & 13.06 & 1.03 & $\% 41.04$ & 9.03 \\
\hline Lying & 8.73 & 1.62 & 12.80 & 0.94 & $\% 46.62$ & 3.56 \\
\hline Total & 25.92 & 4.38 & 38.52 & 2.87 & $\% 48.61$ & 3.98 \\
\hline
\end{tabular}

$\mathrm{p}<(0.05)=2.145$

Table (2) shows statistically significant differences between the pre and post measurements in some physical and technical variables as well as the cognitive tests and behavioral deviations measurements in favor of post measurements.

\section{Discussion}

Throughout the significance differences between pre and post measurements of the physical tests of the research sample which is illustrated in Table (2), it is clear that there are statistically significant differences between the pre and 
post measurements in favor of post measurements in flexibility and aerobic endurance as well as muscular ability, speed and agility, while there were no significant differences between the pre and post measurements in regard to strength endurance. The highest value for (v) calculated in the previous variants of the speed was 9.19 while the lowest value for (v) calculated in the above variables to strength endurance was 1.77 .

Table (2) shows the differences in the percentage of the improvement in the physical variables of basketball between the pre and post measurements which were as follow: $7.7 \%$ in aerobic endurance, $39.46 \%$ in flexibility for post measurement, where the differences in the improvement percentage in the rest of the physical variables was $37.87 \%$, in the muscular ability, $36.16 \%$ in speed, $12.52 \%$ in strength endurance, $27.65 \%$ in agility in favor of post measurement.

The significance differences between pre and post measurements of the offensive basketball technical skills tests for the research sample which is illustrated in Table (2) shows that the value " $\mathrm{T}$ " is greater than the value " $\mathrm{T}$ " in static and peaceful shooting variables as well as passing and interviewing which indicates the statistically significant differences between the pre and post measurements in favor of the post measurement in the offensive skill of basketball. Thevalue of " $\mathrm{T}$ " was 4.07 in static shooting, 2.63 in peaceful shooting, 6.52 in interviewing variable, 9.34 in passing in favor of post measurement.

Table (2) also show that the differences in the percentage of improvement in the offensive skills of basketball between the pre- post measurements was ranged between $19.3 \%$ in the passing technique in basketball, $39.46 \%$ in the static shooting technique in basketball for post measurements. The differences in the percentage of improvement in the peaceful shooting technique in basketball was $37.87 \%$, as for the interviewing skill in basketball, the percentage of improvement was $32.02 \%$.

As for the cognitive skills, Table (2) showsthat the calculated value "T" greater than the table value "T" as the calculated value "T" was 5.46, which indicates statistically significant differences between the pre and post measurements in cognitive skills, and the percentage of improvement in the cognitive skills illustrated in table (2) was $100.00 \%$.

Finally, the significance differences between pre and post measurements shown in table (2) on the behavioral deviations of the research sample. There are statistically significant differences between pre and post measurements in reducing behavior deviations in aggression, disobedience, and lying in favor of post measurement. Thehighest calculated value for $(\mathrm{T})$ in the previous variables to aggression was 9.03 while the calculatedvalue $(\mathrm{T})$ in disobedience was 3.56 and lying 3.58. Thevalue of calculated (T) of the total reduction in behavioral deviations was 4.51 as shown in table (2) that the differences in the percentage of improvement in reducing behavioral deviations between the pre and post measurements was $59.65 \%$ in aggression, while the percentage of improvement in the reduction of the disobedience was $41.04 \%$, and the percentage of improvement in the reduction of lying was $46.62 \%$ in favor of post measurement. Finally, the total percentage of improvement in behavioral deviations was $48.61 \%$.

This result agrees with the opinion of Wafaa Darwish (22), Khalil Michael (7) and Osama Kamel Rateb (3) that the practice of physical activity is one important means to control feelings and emotions and reduce aggression among youngsters. This also agree with the opinion of Fatima Dirar (13) and Walid Abdel Kawi (23) that the practice of sporting activities and regular motion during different technique training makes youngsters accustomed to obey orders and reduce the disobedience of those youngsters. Physical duties assigned to those youngsters also contributed to develop qualities of honesty and truthfulnessamong them (9). Finally this also agreed with David Derezote1995 (26) and Reza Baledi 2011 (31) who stated the possibility of the contribution of basketball in reducing behavioral deviations among youngsters and enhance their social skills.

\section{Recommendations:}

1. Develop sport programs for orphanage children throughout cooperation between Ministry of Sports and Ministry of Social Affairs.

2. Organize training courses and workshops to educate personnel working in orphanage, to help them organize recreational sport activities.

3. Organize recreational sports competitions between orphanages children of different governorates and within the same governorate and award participants with prizes.

4. Develop physical education curriculum for each age category within orphanage which consider the distinctive features of this special group of youngsters

5. Organize recreational sports competitions between children of orphanages and junior basketball players and sport activities in different clubs to integrate those children within society and take advantage of their abilities in the development of society.

\section{References:}

1. Abu Bakr Morsi Mohammed ( 2001 ) : Street Children phenomenon (cross-civilization vision), Moneeb Printing and Publishing House, 1th edition, Cairo .

2. Ahmed Jomaa Awad Jomaa ( 2011 ) : Physical Education programs in Jeddah orphanages, Qadisiyah Journal for Physical Education Science, vol. (11) issue (3) .

3. Osama Kamel Rateb (1997) : Sport Psychology(concepts and applications), 1st edition, Dar al-Kitab al-Arabi, Cairo. 
4. Amal Syed Ahmed (1991) : Building cognitive test in basketball, Unpublished MA Thesis, Faculty of Physical Education for Girls in Cairo, Helwan University, 1991.

5. Ameen Anwar Al-Kholi ( 1996 ): Sports and Society, series of world knowledge, Kuwait .

6. Enshrah Ibrahim Al-Machrafi (2008) : The effect of education program on citizenshipand human rights of orphanage children, 2nd conference of orphan child, charity Association for orphan child, Bahrain .

7. Khalil Michael Moawad (1994) : Growth Psychology - Childhood and Adolescence, $3^{\text {rd }}$ Edition, University Thought House, Alexandria .

8. Zakaria Yusuf El-Sherbini: psychological problems of children (problem - treatment), $2^{\text {nd }}$ edition, Dar al-Fikr, Cairo, 1994. P.77

9. Adel Ramadan Bekhit- Amr abdlla ( 2005 ) : The impact of homework to learn the physical skills of basketball, Faculty of Physical Education for Boys pyramid, Helwan University, Scientific journal of Physical Education and Sports, Vol. 44 .

10. Essam El-Din Abbas Helmy Aldeasity (2002): Methods of teaching and learning Basketball, $2^{\text {nd }}$ Edition, Cairo

11. Ali Al beek -Shaaban Ibrahim (1995): Planning training in basketball, knowledge facility, Alexandria.

12. Emad Mohammed Sayed (2002) : The effect of knowledge as a feedback on learning basketball skills, unpublishedPh.D. thesis, Faculty of Physical Education for Boys, Helwan University.

13. Fatma Al Nabawya Hassaneen Derar(1980): Modify the behavior of female youngsters of orphanage through sports activities, Ph.D. thesis, Faculty of Physical Education for Girls, Helwan University, Cairo. P. 43

14. Mohammed Khamis Abu Namira - Nayef Saada (2008) : Physical Education and teaching methods, the United Arab Companyfor marketing,Al Quds Open University. P. 32

15. Mohamed Mahmoud Abdel Dayem - Mohamed Sobhy Hassanein (1992) : Talking about basketball, $2^{\text {nd }}$ Edition, Arab Thought House, Cairo.

16. Mahmoud Al-Said Rawy (2010): The effectiveness of Psycho-physical program in reducing the level of behavioral deviations among orphanage children, Unpublished MA Thesis, Faculty of Physical Education, Banha University.

17. Medhat Saleh(2004):Educational and training programs in basketball, Al Qalam Publishing and Distribution House, First Edition, Cairo.
18. Marwa Yousef Al-Dahshouri (2004 ) : The effect of educational sport program target the level of fitness and some social and psychology variants of orphanage, Ph.D. thesis, Faculty of Physical Education for Girls, Helwan University.

19. Mona Mahmoud Mohammed et all ( 2008 ) : social and psychological problems of children of unknown parentage within alternative families and orphanages, Umm Al Qura University, Faculty of Education .

20. Nagah -Nassif (1993) : Social growth and selfconfidence in children deprived of their parents and normal children, comparative study, unpublished Master Thesis, Faculty of Physical Education, King Saud University.

21. Naglaa Abbas Mohammed : the impact of a proposed sport program on some non-cognitive aspects of orphanage children in Assiut, Master Thesis, Faculty of Physical Education for Girls, Assiut University, 1999. P. 153

22. WafaDarwish- Sabah Ali: the impact of the practicing certaintypes ofcombatson theaggressive behaviorof reformatory ofthe age group 9-12years

23. Walid Abdel Qawi Abdel Wahab (2002): The effect of sport program on some behavioral problems among orphanage children in Minia Governorate, Master Thesis, Faculty of Physical Education for Boys, Minia University.

24. Yasser Abdel Fattah Mohamed(2000) : The effect of arranging offensive technical teaching of basketball on the level of performance, Master Thesis, Faculty of Physical Education for Boys in Cairo, Helwan University.

25. Burrallpaye - Patrick paye 2001: Youth Basketball Drills, human kinetics .U.S.A.

26. DerezoteDavid,ph.d 1995 : Evaluation of the late nite Basketball project, child and adolescent Social work, Journal, Volume 12 - Number 1 .

27. Hal Wissel 1994: Basket Ball "Steps to success" Human Kinetics, U.S.A. p.1

28. Jeff \& Joe Haefner : 60 Fun Basketball Drills and Games for Youth Coaches , Break through Basketball , 1lc , 2008

29. Jerry V. Krause - Don Meyer - Jerry Meyer 1999 :Basket Ball Skills \& Drills, Second Edition, human kinetics U.S.A .

30. Somen, Suman 1984 : Mental health problems of children in orphanages, paper presented at Social work and clinical setting

31. Reza Baledi2011: the effect of ten weeks basketball exercise on social development in Adolescents of Ahwaz City , Procardia - Social and Behavioral Sciences., Volume (15). 
